\title{
Syncretism in the church of Philippi
}

\author{
Eduard Verhoef ${ }^{1}$ \\ Maartensdijk, The Netherlands
}

\begin{abstract}
It has been known for a long time that the history of Christianity has seen the incorporation of syncretistic elements. This is not at all exceptional. On the contrary, in order to grow, any religion necessarily fits in with the existing frame of reference. It is hardly surprising then, that elements of Hellenistic hero worship were adopted in the veneration of the Christian martyrs. Over a century ago, E Lucius presented several examples of such phenomena in his book, Die Anfänge des Heiligenkults in der christlichen Kirche (1904), arguing that Christian churches adopted several rituals and ideas from older pagan cults. Indeed, excavations in Philippi have revealed a connection in the first decades of the fourth century between the Christian cult and the cult of a certain Euephenes, son of Exekestos. He was probably an initiate into the mystery cult of the Kabeiroi. This can only mean that in Philippi as elsewhere syncretistic elements must have crept in. In the beginning of the fourth century the Basilica of Paul was added onto the Hellenistic shrine, so that the buildings shared one wall. In the first half of the fifth century this Basilica was replaced by the bigger Octagon. A baptistery was constructed, and the Hellenistic heroon was incorporated into these buildings. Around this time the cult of the Hellenistic hero Euephenes was supplanted by the veneration of the Christian hero par excellence, the apostle Paul.
\end{abstract}

\section{INTRODUCTION}

The Octagon and the surrounding area in Philippi were excavated in the period of 1958 through 1982. Reports of these excavations can be found

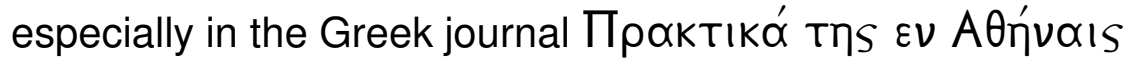

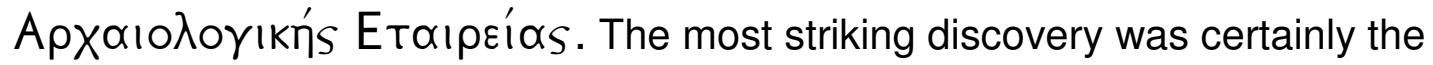
tomb of a Hellenistic hero. This tomb was the centre of a cult that was

\footnotetext{
${ }^{1}$ Dr Eduard Verhoef, Maartensdijk, the Netherlands, participates in the research project "Biblical Theology and Hermeneutics", directed by Prof Dr Andries G van Aarde, honorary professor of the Faculty of Theology, at the University of Pretoria. The author would like to thank Mrs Dra J W van Arenthals for her critical remarks on this text.
} 


\section{Syncretism in the church of Philippi}

continued at least up to the middle of the fourth century $A D$, i.e, the time that Christians received permission to practice their own religion (Bakirtzis 1998:43). A shrine was built above the tomb. In this time, the first Christian church was built in Philippi (Pelekanidou \& Mentzos 1990:597-598). This church was erected right up against the Hellenistic shrine so that both buildings had one wall in common. Around the year 400 a new, bigger church was built, an Octagon. Archaeological discoveries and inscriptions make it possible to gain an insight into this holy site and the matters relating to it. Based on the available data I will sketch the developments in these centuries and I will pay attention especially to the way the Hellenistic cult was succeeded by Christian rituals.

\section{THE HELLENISTIC HERO AND THE CULT AROUND HIS TOMB}

Immediately north of the Octagon a tomb was found in a subterranean burial chamber. This tomb measures 1.19 by 0.62 meters, its height is 0.59 meters (Gounaris 1990:56). The size of this tomb suggests that it was meant for a child or for "a very short adult" (Koukouli-Chrysantaki 1998:20). An inscription

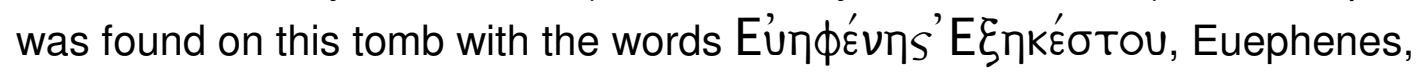
son of Exekestos. ${ }^{2}$

According to the archaeologists this tomb dates from the second century BC (Koukouli \& Bakirtzis 1995:54; Gounaris \& Gounari 2004:77). Lazaridis $(1964: 374)$ dated the tomb in the third century BC. It is striking that it was situated within the city walls because it was forbidden to bury people within a city and only heroes and dignitaries were allowed that (Koukoules 1951:185188; Gounaris 1990:56; Sève 2000:193). Consequently this Euephenes must have been an important man (Lazaridis 1964:373). Golden treasures found in his tomb confirm this.

Recently Aristoteles Mentzos argued that this tomb was located outside

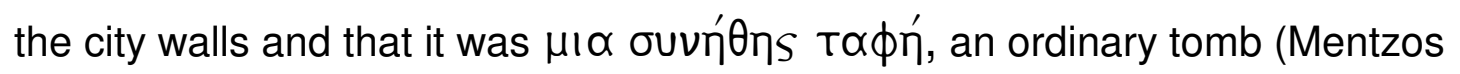
2005:117). In his article Mentzos states that the people of Philippi lived on the slope of the acropolis and that the flat area at the foot of the hill was hardly inhabited. But this is extremely improbable. Remnants of the Hellenistic walls have been found and they have been used as foundations for the later walls (Roger 1938:21 and drawing I; Lemerle 1945:147-148 and drawing I; Provost \& Boyd 2002:95-96; Gounaris \& Gounari 2004:21-26). Consequenty the trajectory of the walls of Philippi is well known (Sève 2000:191-192). These walls were about 3400 meters long (Lazaridis 1973:44), surrounding both the

\footnotetext{
${ }^{2}$ Perhaps a third word could partly be read: -vos. Cf Pilhofer (2000:334-336).
} 
acropolis and a flat area. The flat part of the walled zone and the lower parts of the acropolis were both inhabited (Lazaridis 1973:31). The tomb of Euephenes was situated within these city walls.

\section{WHO WAS THIS EUEPHENES?}

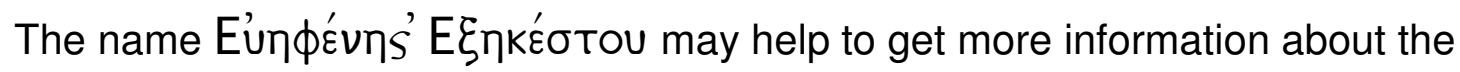
deceased. Besides the inscription found on this tomb, the name Eun $\phi^{\prime} v_{\eta}{ }_{S}$ occurs, to my knowledge, only in the following inscriptions. ${ }^{3}$

- It is mentioned in an unpublished inscription that was found in Philippi. In this inscription Euephenes, son of Exekestos, has the role of "an initiate into the mystery cult of the Cabiri at the Sanctuary of Samothrace" (Koukouli \& Bakirtzis 1995:54; Pilhofer 2000:336). This Euephenes is probably the same person mentioned in the subterranean tomb (Koukouli \& Bakirtzis 1995:54).

- $\quad$ This name occurs in an unpublished inscription from Samothrace. It is striking that this one is related to the mystery cult of the Kabeiroi as well (Pelekanidis 1978b:395-396).

- We read this name in an inscription from the nearby island of Thasos. It is dated in the fourth century BC. This inscription says that several persons did a dedication. The sixth person mentioned is $\triangle \varepsilon$ EIVó $\mu \propto X O S$

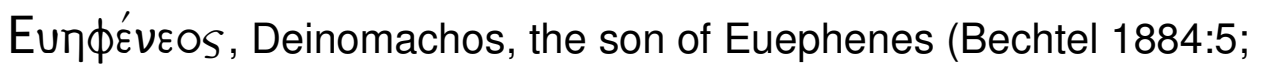
Demitsas 1988 [1896]: number 1187; Fredrich 1909: number 376).

The namé $E \xi \eta K \varepsilon ́ \sigma T O S$ is used in many more instances. An interesting

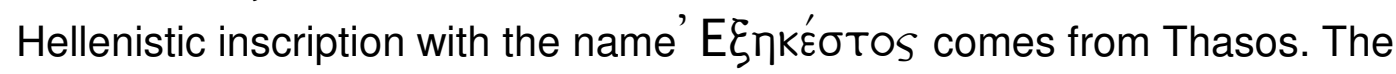
inscription says that the people of Thasos honoured the Philippian, son of Exekestos (Pilhofer 2000:723-724). This presumably refers to the person mentioned above (Pelekanidis 1978b:395).

On the basis of these inscriptions and of the golden treasures found in this tomb, Pelekanidis thought it very probable that this Euephenes was related to a mystery cult and that he belonged to a distinguished family of Philippi (Pelekanidis 1978b:396). Later on Pelekanidis said without any hesitation that this Euephenes was initiated in the cult of the Kabeiroi, óvtas

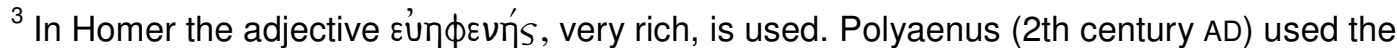
slightly different name Eúńфevos twice.
} 


\section{Syncretism in the church of Philippi}

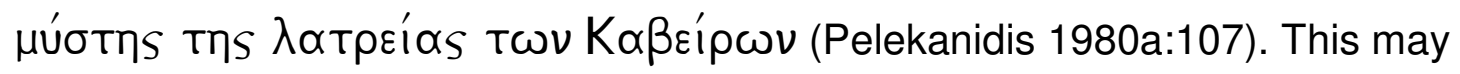
be right because of the two inscriptions in which this name is used in connection with the cult of the Kabeiroi. The very rare occurrence of the name Euephenes can be seen as a confirmation of the assumption that one and the same person is meant in the inscription on the tomb and in the two inscriptions that connect Euephenes with the cult of the Kabeiroi.

\section{THE SHRINE}

A triple stepped podium was built above the subterranean burial chamber. This podium was 0.5 meters higher than the surrounding area (Pelekanidis 1980b:154; Gounaris 1990:55). In this way a dais was made of 4.7 by 6 meters. Around this dais an enclosure was constructed so that a temenos, a precinct, was formed of about 550 square meters (fig 1). A shrine was built on the dais, belonging to the hero who was buried in the subterranean chamber. He may have been worshipped as the founder of the city (Pelekanidis 1980b:154-155). Roman coins that were found at the bottom of the shrine confirm that this shrine had a cultic function (Gounaris \& Gounari 2004:77).

\section{SIMILAR SHRINES}

We know of several similar shrines in the Greek world. Martin lists nearly thirty of them (Martin 1951:194-201). Well-known is the cult of the mythological Aeacus, the hero of the island of Aegina. He was famous for preventing pirates from entering into the harbour and for imploring Zeus to make it rain. Another shrine was dedicated to him in Athens (Herodotus Histories V, 89; Pausanias II.29, 6-8). A comparable site has been excavated in Ephesos where the heroon of Androklos, the supposed founder of the city, was situated in the city center (Thür 1995a:174-177; Thür 1995b:63-103). In Amphipolis the brave Brasidas was buried within the city. He was venerated as the founder of Amphipolis. The Amphipolitans made an enclosure around his tomb, brought offerings every year and held games in his honour (Thucydides V.11, 1). What exactly the cult of such a hero was like is most often unknown. The same is the case with regard to Philippi. Offerings, dances, singing, feasts are all ways in which the hero may have been venerated. Herodotus (Histories V, 67) argued that offerings, feasts and tragical dances formerly played a role in the rituals in honour of Adrastus, who was venerated as a hero in Sicyon (cf Habicht 1956:138-159, 200-205). In any case it is clear that the place of the burial chamber, the dais with the shrine and the precious gifts point to a cult of a local hero, Euephenes, son of Exekestos. 


\section{EUEPHENES AND KABEIROS}

In my opinion it is certain that this Euephenes was related to the mystery cult of the Kabeiroi on the island of Samothrace. Already in 1977 R Witt defended "the Kabeiric presence" on Samothrace (Witt 1977:965). In my opinion Witt was right with this statement, but we do not know exactly how Samothrace and the Kabeiroi are related with Philippi. A connection between the Kabeiroi and Samothrace was made in the two inscriptions mentioned above. This connection is confirmed by other statements. Plutarch, Macellus 30.4, refers

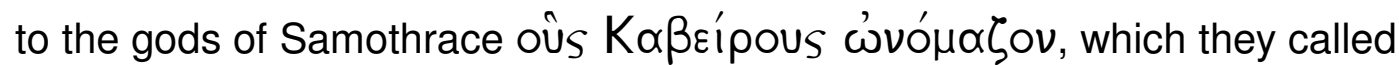

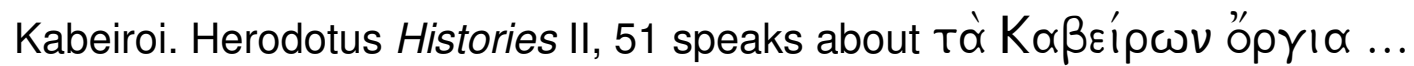

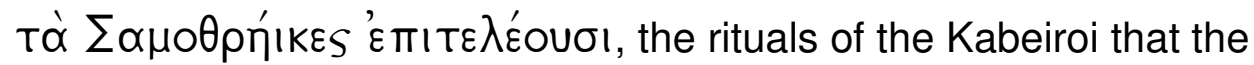
Samothracians performed. ${ }^{4}$ Cole states that the "term Kabeiroi [...] never appears at Samothrace" (Cole 1984:1). But a connection between the Kabeiroi, Philippi and Samothrace cannot be denied. In the two unpublished inscriptions mentioned above the Kabeiroi are certainly connected with Samothrace and one of these inscriptions was found in Philippi (Pelekanidis 1978b:395-396; Koukouli \& Bakirtzis 1995:54; Pilhofer 2000:336). ${ }^{5}$ Cole herself mentions an unpublished inscription about four Samothracian initiates from Philippi (Cole 1984:25.113), and an inscription found at Samothrace that mentions both an initiate from Philippi and an initiate from Thasos (Cole 1984:44.171; cf Fraser 1960:59-60; Pilhofer 2000:706-707). In these two inscriptions the Kabeiroi are not mentioned, but the connection between Philippi and Samothrace is clear.

Another interesting inscription possibly originates from Amphipolis. It is an epitaph dated after the second century BC (Karadima-Matsa \& Dimitrova 2003:335-338). In this inscription a connection is made between the cult of Kabeiros and the cult of Demeter in Eleusis. It is said that a certain Isidoros, the son of Nikostratos, ${ }^{6}$ as an initiate saw the double holy light of Kabeiros among the Samothracians and the holy rites of Demeter in Eleusis. The mention of just one Kabeiros in this inscription is striking, as most often the plural Kabeiroi is used, though in Thessaloniki as well just one Kabeiros was

\footnotetext{
${ }^{4}$ More authors made a connection between Samothrace and the Kabeiroi; see Lewis (1959:70-95).

${ }^{5}$ It is fascinating to realise that the word "great", used for the $\theta \varepsilon \circ i \mu \varepsilon \gamma \alpha^{\prime} \lambda o$, in Hebrew could be rendered by כבר and in later Arabic by 'kabīr'. Both words remind of the name Kabeiroi; see also Job 34:17; 36:5 where כבר כion used for God. But an etymological connection between the name Kabeiroi and a Semitic word cannot be proven. Burkert (2002:58-59) thinks this connection to be very probable; but see Beekes (2004:474-476).

${ }^{6}$ Karadima-Matsa \& Dimitrova (2003:337) seem to think that this man is named Isidoros Nikostratou.
} 


\section{Syncretism in the church of Philippi}

venerated in Roman times. The Kabeiric cult could have played a role in Amphipolis as well (cf Papastavru 1936:54, 97). His shrine in Thessaloniki was probably located in the area of the later Church of Saint Demetrios (Tzanavari 2003:229-230), which is in the centre of the old city, just like the shrine of Euephenes in Philippi.

It is striking that the size of the tomb in Philippi points to a child or a very short adult, as we realise that in Thessaloniki Kabeiros was often depicted as a child standing on the hand of the goddess Nike (Hemberg 1950:208-209). With respect to Thessaloniki it is sometimes argued that the cult of Kabeiros originated from the island of Lemnos, where Kabeiros was seen as a young God (Hemberg 1950:163-165).

\section{THE BASILICA OF PAUL}

The first Christian church of Philippi was built in the beginning of the fourth century, shortly after the so-called Edict of Milan in 313 (Pelekanidis 1976:124; Pelekanidis 1980a:109-110). At that time the Christian community of Philippi may have consisted of more than 1000 members (Verhoef 2005:577). An inscription tells us that bishop Porphyrios made a mosaic floor in this Basilica of Paul. ${ }^{7}$ Porphyrios is known to have joined the Synod of Sardica in 342-343. This church was a simple basilica with a short, wide apse. On the outside it measured 27.5 by 9.9 meters (Pelekanidis 1978a:70). It is not explicitly said that this church was named after the apostle Paul. For this reason Gounaris argues that this church was named after a certain martyr

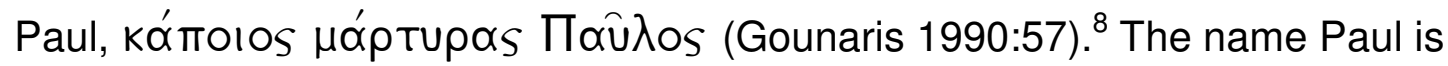
used twice in other inscriptions found in Philippi. An epitaph mentions Paul, the presbyter and physician of the Philippians. In another one it is spoken of Paul, the presbyter of the holy church of the Philippians (Pilhofer 2000:96-99). But in my opinion the name Paul without any epithet refers to the apostle Paul. This is all the more probable as we realise that the Philippians were the first people on the European mainland to be visited by the apostle. ${ }^{9}$ He was their great hero.

This basilica was constructed in such a way that the Hellenistic heroon was left intact. The south side of the Hellenistic heroon was used as the north

\footnotetext{
${ }^{7}$ For the enthusiastic report on the discovery of this inscription see Pelekanidis (1975:99102).

${ }^{8}$ Gounaris argued in 1984 that this church "était consacrée à St. Paul, fondateur de l'Église de Philippes" (Gounaris 1984:138).

${ }^{9}$ Pelekanidis (1980a:107) and Bakirtzis (1998:42) also argued that this church was called after the apostle Paul.
} 
wall of the church. The church's south wall was in fact the old southern enclosure of the precinct of the heroon (Bakirtzis 1998:42-43); see figure 2. The foundation of the south wall has been found under the floor of the Octagon, which was built later (Pelekanidis 1976:124-128). A door between the courtyard of the Hellenistic shrine and the church shows that people could go from this shrine into the church and vice versa. An inscription in the church's mosaic floor says: Christ, help your servant Priscus and all his family. This inscription was oriented from east to west. According to Bakirtzis it was apparently intended to be read by people entering from the courtyard of the heroon (Bakirtzis 1998:43). ${ }^{10}$ Bakirtzis concludes that in the beginning of the fourth century "the pagan and Christian sanctuaries were functioning simultaneously side by side" (Bakirtzis 1998:43; cf Pelekanidis 1978b:396). This Basilica of Paul presumably burned down at the end of the fourth or at the beginning of the fifth century.

\section{THE OCTAGON}

A new church, an Octagon, was built shortly after (Bakirtzis 1987:150; Pelekanidou \& Mentzos 1990:600.604); see figure $3 .{ }^{11}$ Parts of the Basilica's north wall, i.e., the heroon's south wall, survived, but the Basilica's south wall was levelled to make room. More important for the scope of this paper are the annexes that were constructed to the north of the Octagon (see figure 3): a fountain (I), ${ }^{12}$ a hall (II), a four-room baptistery consisting of a dressing room (III), a catechumen's room (IV), a room with the baptismal font (V) and a socalled chrismarion (VI), and finally a diaconicon (VII) and a prothesis (VIII). The storage space of the Balneum was sacrificed in order to make possible the construction of this rather large baptistery (Gounaris and others 1982:35; Gounaris 1990:31.42-43). And the south wall of the Balneum was partly pulled down in order to create a square room for the cruciform baptismal font (Gounaris 1990:42). The rooms of the baptistery were constructed around the older sanctuary with the result that the baptistery was rather far from the narthex (Gounaris 1990:44). Pelekanidis (1960:88) speaks about an anomaly with respect to the lay-out. The south wall of the catechumen's room and of the room with the baptismal font was the north wall of the temenos of the heroon (Gounaris and others 1982:36). This shows that the Hellenistic shrine was intentionally left intact in spite of the fact that Christianity had become a

\footnotetext{
${ }^{10}$ For the exact location of this inscription see Pelekanidis (1978a:72).

${ }^{11}$ A later expansion of the Octagon (Mentzos \& Pelekanidou 1990:604) does no have any consequences for this article.

${ }^{12}$ According to Mentzos (1995:525-530) it was a Byzantine hydraulic clock.
} 


\section{Syncretism in the church of Philippi}

state religion at the time. But this shrine was now surrounded at all sides by the buildings of the Christian cult. Non-Christian cults were officially forbidden by Theodosius in 380 . What then, can have been the role of this shrine in the fifth century and later? Archaeological finds may help find an answer.

Especially the discoveries in the diaconicon and in the prothesis are important in this regard.

The most interesting finds are a rectangular marble reservoir in the diaconicon and a smaller round cistern in the adjacent prothesis. The marble reservoir measures 1 by 2.5 meters, its height is 0.93 meters (Gounaris 1990:51). In the upper part of the reservoir a marble slab was fastened in order to create a shallow basin (Gounaris 1990:51; Bakirtzis 1998:46). Fresh water entered it from the Balneum. Some of this water was led to the cistern in the prothesis. This water was regarded holy water. Gounaris speaks of a

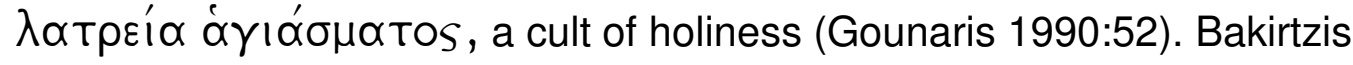

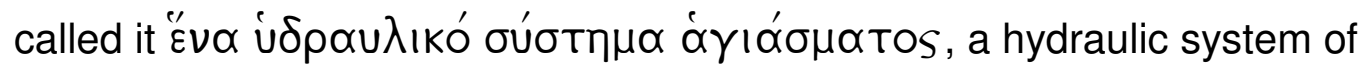
holiness (Bakirtzis 1997:502). The excess water was drained away through a pipe (Gounaris 1990:51-54 and figure 4 in Gounaris' book). It has been established that the marble reservoir had a baldachin. The holes for the small columns to support this baldachin are still to be seen (Gounaris 1990:52 and figure 12 in Gounaris' book). Bakirtzis thought the marble structure to be a "sarcophagus-cenotaph" and argued that it contained "sacred relics". "Holy water from the martyr's tomb brought the worshipper into contact with the martyr's gracious power" (Bakirtzis 1998:46-47; cf Bakirtzis 1997:502-503).

It is impossible to decide with certainty which martyr was supposed to grant his power here, though a connection with the apostle Paul is likely. Of course this does not mean that Paul was buried there. Bakirtzis asks suggestively: "Whose tomb was this? Why not Saint Paul's?" (Bakirtzis 1998:47). Koester goes even further. He argues that the evidence for the martyrdom of Paul in Rome is rather weak and he tries to prove that a martyrdom of Paul in Philippi is very well possible (Koester 1998:63-65). I agree that the evidence for the martyrdom of Paul in Rome is not strong, but in my opinion the evidence for a martyrdom in Philippi is even weaker. Moreover, a martyrdom of Paul in Philippi would have been well documented. Notwithstanding this the $\lambda \propto т \rho \varepsilon^{\prime} \alpha \stackrel{\alpha}{\alpha} \gamma ı \alpha^{\prime} \sigma \mu \alpha \tau$ Tos in the diaconicon and in the prothesis will have been related to Paul. The name of the first basilica reminds of him though after the collapse of this church his name disappeared in the rubble. But we can imagine that even after the collapse of the Basilica of Paul the Christians in Philippi were inclined to honour their hero, the apostle Paul (Brenk 2003:8). And though we have no evidence, it is very well possible that the Octagon was named after Paul, as was the first basilica. 
The phenomena in the diaconicon and the prothesis can only be interpreted as parts of a specific ritual that was connected with the Octagon and with the annexes built around the heroon. Such rituals were not exceptional. In Ma'in, Seleucia in Isauria, Abu Mina, Thessaloniki and elsewhere holy water or holy oil played an important part in Christian rituals around holy persons. A comparable cult must have taken place in Philippi, where a Christian martyr was venerated. The veneration of the martyr will have replaced the cult of the Hellenistic hero. The octagonal form of the newly built church in Philippi can be seen as a confirmation of the existence of a martyr's cult here (Grabar 1972:145-146).

Pelekanidis argues that there is a link between these rituals in Philippi and the cult of Demetrios in Thessaloniki. Immediately north of the apsis of the Octagon another marble reservoir was excavated (Pelekanidis 1966:49; Orlandos 1967:43-44). In this reservoir potsherds were found that could be restored to pottery comparable with pottery found elsewhere. Pelekanidis wondered if these finds could be interpreted in the same way as the lead phials found in the crypt of the Church of Saint Demetrios in Thessaloniki, i.e that they served a specific religious purpose in a particular cult (Pelekanidis 1966:50). But these so-called koutrouvia are most often dated around the year 900 or later (Bakirtzis 1982:524-525), whereas Philippi began to decline in the seventh century because of earthquakes and raids of northern tribes (Lemerle 1945:113-118). Moreover we know now that later excavations in Philippi did not confirm Pelekanidis' suggestion. Be that as it may, in the diaconicon and

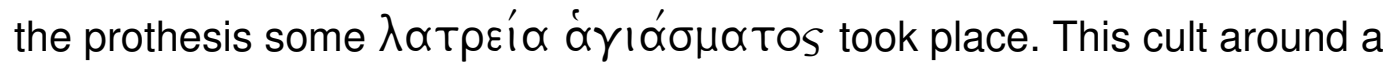
martyr's remains will have been related to the illusory body of Paul. It is wellknown that Ambrosius is supposed to be the first person to open tombs of martyrs in 386 in order to give the mortal remains to a church. Nonetheless the Fathers sometimes warned against overestimation of rituals around the tombs of martyrs. ${ }^{13}$

\section{SYNCRETISM IN PHILIPPI}

Information is scarce but on the basis of the data above I conclude that in Philippi a Hellenistic cult was supplanted by the adoration of a Christian hero or martyr in the time that the shrine was incorporated into the Christian buildings. Evidently this change cannot be dated at a specific time. It must have been a gradual development (Sève 2000:198 speaks about "un culte héroïque progressivement christianisé"), but in my opinon we can be sure that the construction of the Basilica of Paul in about 320 and the building of the

\footnotetext{
${ }^{13}$ See Jerome, Contra Vigilantium 9 and Letter 109.
} 


\section{Syncretism in the church of Philippi}

Baptistery somewhere around the year 400 are milestones in this development. It is interesting to note that the Emperor Julian the Apostate was amazed about the similarities between the cult of a hero and the adoration of Christian martyrs (Bidez 1924:86). Soon after the time Christians were permitted to build their own churches, in the second decade of the fourth century, the Christians in Philippi erected their first church. As was often the case, they built this church upon ground that belonged to an existing sanctuary (Pelekanidis 1980b:154). Apparently the Christians could use a part of the courtyard of the Hellenistic shrine. But the way in which they built their church shows that the Hellenistic shrine remained in use. Less than seventy years later Christianity was established by Theodosius as the only permitted religion. Of course this did not mean that other religions disappeared immediately, ${ }^{14}$ but they declined and slowly but surely Christianity took their place. When the Christians in Philippi built a new large church in the place of the Basilica of Paul and incorporated the old Hellenistic shrine, it must have been to do with the local cult that they did not want to give up entirely. They upheld it and made it a part of local Christian worship (Gregory 1986:237; Pelekanidis 1967:124).

Later Pelekanidis (1980a:107) argued that Christianity used pagan forms

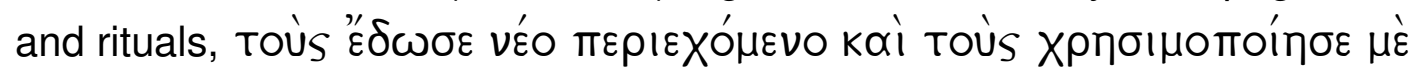

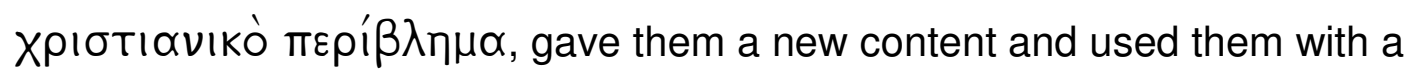
Christian dress. Earlier, at a 1977 meeting, Pelekanidis had used the word

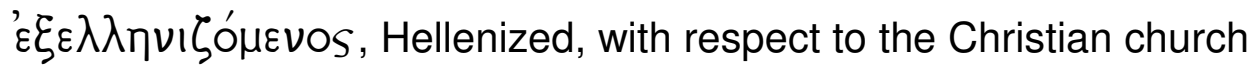
(Pelekanidis 1980b:155). It is interesting that Dyggve \& Poulsen \& Rhomaios (1934:125-126) reached similar conclusions with respect to the heroon of Kalydon. See also Price (1999:169) with respect to the cult of Asclepios in Athens: "the ancient functions of Asclepios may have been incorporated into the new Christian structures."

Comparable phenomena can be seen elsewhere. More than a century ago, in 1904, E Lucius published his study, Die Anfänge des Heiligenkults. In this interesting book Lucius states that several local cults were replaced by the new Christian cult. ${ }^{15} \mathrm{He}$ argues that local heroes or deities were often succeeded by Christian martyrs. Lucius gives the example of the goddess Athena mentioned above. In Seleucia in Isauria she was succeeded by Thecla. Athena as the main goddess of Seleucia was often depicted on local

\footnotetext{
${ }^{14}$ The sanctuary of Asclepius in Athens continued to be popular until the second half of the fifth century (Price 1999:168-169).

${ }^{15}$ In the same way the Greek gods sometimes got other functions in Asia Minor (Pilhofer 2006:144-145).
} 
coins. A sanctuary was built in her honour on the top of one of the mountains. She was venerated as the tutelary deity. In the first half of the fifth century Basileios, bishop of Seleucia wrote about Thecla, about miracles she performed and about her protection of the city (Migne $1844 \mathrm{vol} 85,477-618$ ). The similarities between Thecla's activities and the former role of the goddess Athena are so clear according to Lucius that he mentions her as Athena's heiress and as the woman who conspicuously continued Athena's activity (Lucius 1904:208; cf Davis 2001:75-77). I do not need to repeat more examples by Lucius of similar developments in the Roman Empire. What is important here is that such things happened. Examples include Ma'in, Seleucia, Abu Mina and Thessaloniki, and also Philippi. ${ }^{16}$

Of course such developments are an indication of syncretism. Several elements of the former cult were adopted into a new cult, in this case Christianity. Penna (1995:226) argues with respect to an underground grave complex outside the city that "The society of the Roman colony of Philippi [...] seems to have incorporated Christian worship into the pagan pace of life". The Christians in Philippi built their church on holy ground and the Hellenistic shrine was not levelled to the ground, but was adopted with the emotional value attached to it. The cult around this shrine was continued in Christianity, though rather than the Hellenistic hero a Christian was venerated who in my opinion is the apostle Paul (Brenk 2003:38). The marble reservoir and the smaller, round cistern with the holy water were used in rituals which must be assessed against the background of the upcoming adoration of martyrs in Abu Mina in Egypt, in Ma'in and elsewhere. The holy water was probably taken along in eulogiae, small phials made of glass, earthenware or lead. In the view of the pilgrims it embodied the blessing of the adored martyr. They participated in these blessings by a devout attitude towards the holy person to which the shrine belonged.

Peter Brown objects to the statement that in several cases the cult of Hellenistic heroes was supplanted by the cult of a Christian martyr or a saint. He argues that the role of Christian martyrs was very different because in his opinion not any Hellenistic hero had the function of an intercessor, whereas the Christian martyrs did have that role (Brown 1983:6). But in spite of possible differences between Hellenistic heroes and Christian martyrs, it is evident that in Philippi the cult of the former hero was supplanted by the cult of a Christian saint.

\footnotetext{
${ }^{16}$ It is fascinating that in Thessaloniki the cult of Kabeiros was probably succeeded by the cult of Saint Demetrios (Vitti 1996:92; Bakirtzis 1997:508; Tzanavari 2003:230).
} 


\section{Syncretism in the church of Philippi}

\section{CONCLUSION}

The older cult of Euephenes, the son of Exekestos, was incorporated in Christianity in Philippi. Euephenes was an initiate of the Kabeiric cult on Samothrace. Several older elements were preserved in the new Christian cult: the holy ground, the shrine and some rituals around the tomb. These elements were christianised. This Christianisation did not happen on a specific day, but the older traditions were integrated into the Christian ceremonies in a process of decades. The upcoming veneration of martyrs in several cities in the Roman Empire helped the Philippians to find a framework for the cult around the Hellenistic shrine. Instead of Euephenes it was the apostle Paul who was venerated now.

\section{Works consulted}

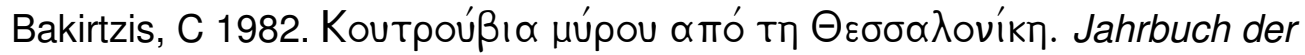
Österreichischen Byzantinistik 32, 523-529.

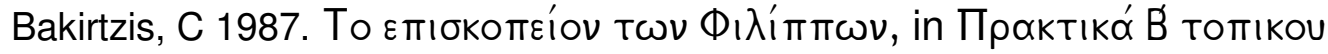

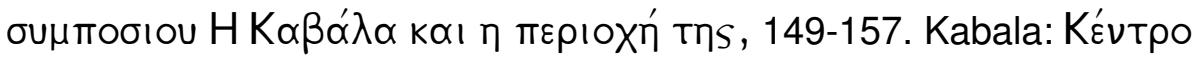

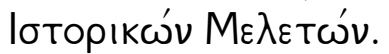

Bakirtzis, C 1997. Ayíou $\triangle \eta \mu \eta t \rho i ́ o v ~ \Theta \alpha u ́ \mu \alpha \tau \alpha$. Thessaloniki: Agra.

Bakirtzis, C 1998. Paul and Philippi: The archaeological evidence, in Bakirtzis, C \& Koester, H, Philippi at the time of Paul and after his death, 37-48. Harrisburg, PA: Trinity.

Bechtel, F 1884. Thasische Inschriften ionischen Dialekts im Louvre. Göttingen: Dieterich.

Beekes, R S P 2004. The origin of the Kabeiroi. Mnemosyne 57, 465-477.

Bidez, J 1924. L'empereur Julien: Oeuvres complètes I.2. Paris: Les belles lettres.

Brenk, B 2003. Die Christianisierung der spätrömischen Welt. Wiesbaden: Reichert. (Spätantike - frühes Christentum - Byzanz. Reihe B: Studien und Perspektiven 10.)

Brown, P 1983. The cult of the saints. Second Impression. London: SCM.

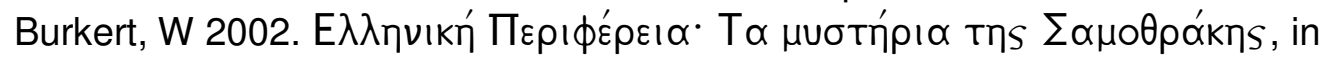

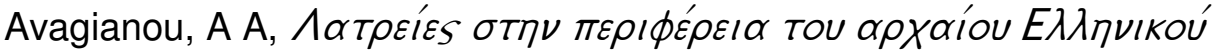

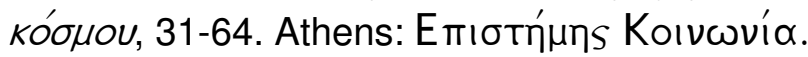

Cole, S G 1984. Theoi Megaloi: the cult of the great gods at Samothrace. Leiden: Brill. (Études préliminaires aux religions orientales dans l'Empire Romain 96.)

Davis, S J 2001. The cult of st Thecla. Oxford: University Press. (Oxford Early Christian Studies.)

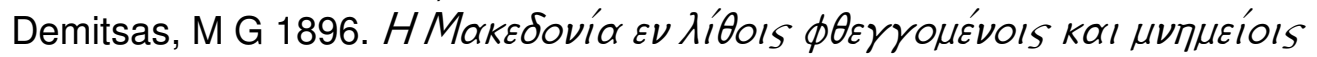
$\sigma \omega \zeta$ oúvols II. Athens: Perri. (Reprint Thessaloniki 1988.)

Dyggve, E \& Poulsen, F \& Rhomaios, K 1934. Das Heroon von Kalydon. København: Levin \& Munksgaard.

Fraser, P M 1960. The inscriptions on stone: Samothrace. New York: Pantheon. (Bollingen Series LX.2.1.)

Fredrich, C 1909. Inscriptiones Graecae XII.8. Berlin: Georgius Reimerus. 
Gounaris, G G, Mentzos, A, Bakirtzis, A, Bakirtzis, C \& Pelekanidou, E 1982.

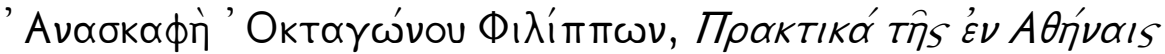

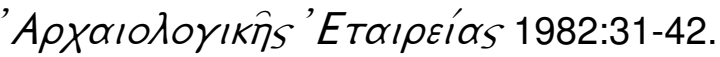

Gounaris, G G 1984. Le problème de l'existence de deux ambons dans l'Octogone de Philippes, Actes $d u^{\mathrm{Xe}}$ Congrès International d'Archéologie Chretienne II, Rom/Thessaloniki, 133-140.

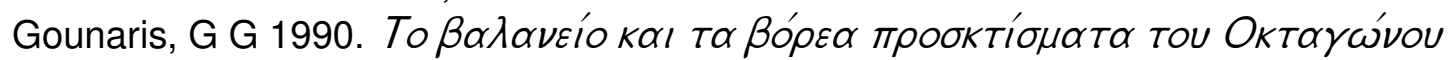
$\tau \omega \nu \Phi_{1} \lambda i \pi \pi \omega \nu$. Athens: Archaeological Society.

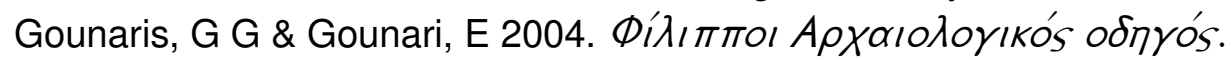

Thessaloniki: University Studio Press.

Grabar, A 1972. Martyrium: Recherches sur le culte des reliques et l'art chrétien antique I. Architecture. London: Variorum Reprints.

Gregory, T E 1986. The survival of paganism in Christian Greece: A critical essay. American Journal of Philology 107, 229-242.

Habicht, C 1956. Gottmenschentum und griechische Städte. München: Beck. (Zetemata 14.)

Hahn, C 1990. Loca Sancta souvenirs: Sealing the pilgrim's experience, in Ousterhout, R (ed), The blessings of pilgrimage, 85-96. University of Illinois, IL: Chicago.

Hemberg, B 1950. Die Kabiren. Uppsala: Almquist \& Wiksells.

Karadima-Matsa, C \& Dimitrova, N 2003. Epitaph for an initiate at Samothrace and Eleusis. Chiron 33, 335-345.

Koester, H 1998. Paul and Philippi: The evidence from Early Christian literature, in Bakirtzis, C \& Koester H, Philippi at the time of Paul and after his death, 4965. Harrisburg, PA: Trinity.

Koukoules, P 1951. Vie et civilisation Byzantines IV. Athènes: Institut Français.

Koukouli, C \& Bakirtzis, C 1995. Philippi. Athens: Ministry of Culture.

Koukouli-Chrysantaki, C 1998. Colonia lulia Augusta Philippensis, in Bakirtzis, C \& Koester $\mathrm{H}$, Philippi at the time of Paul and after his death, 5-35. Harrisburg, PA: Trinity Press International.

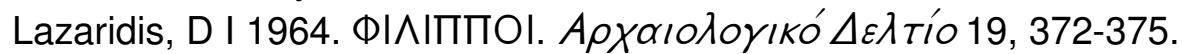

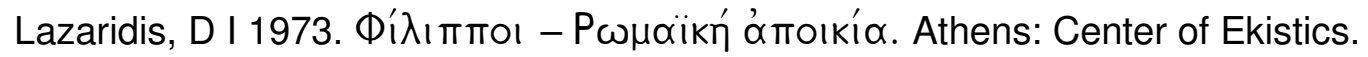
(Ancient Greek Cities 20.)

Lemerle, P 1945. Philippes et le Macédoine orientale à l'époque chrétienne et byzantine I. Paris: Boccard. (Recherches d'histoire et d'archéologie 1.)

Lewis, N 1959. Samothrace: The ancient literary sources. London: Routledge \& Kegan Paul. (Samothrace I, ed Lehmann, K.)

Lucius, E 1904. Die Anfänge des Heiligenkults in der christlichen Kirche. Tübingen: Mohr.

Martin, R 1951. Recherches sur l'Agora Grecque: Études d'Histoire et d'Architecture Urbaines. Paris: Boccard.

Mentzos, A 1995. A byzantine hydraulic clock from Philippi, Pact 45, 525-530.

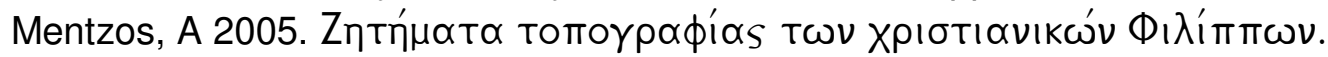
EГNATIA 9, 101-156.

Migne, J P 1844. Patrologiae Cursus Completus. Paris: Garnier. (Series Graeca 85.)

Orlandos, A K (ed) 1967. Фı To $1966,42-54$. 


\section{Syncretism in the church of Philippi}

Papastavru, J 1936. Amphipolis: Geschichte und Prosopographie. Leipzig: Dieterich.

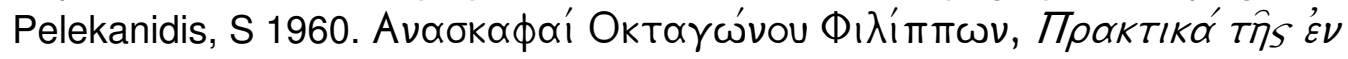

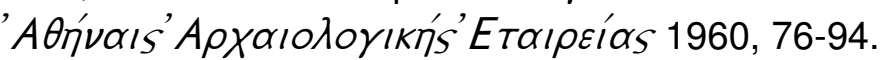

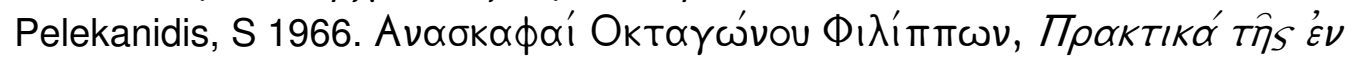

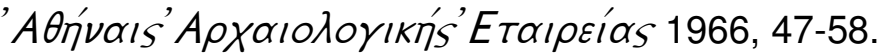

Pelekanidis, S 1967. Excavations in Philippi. Balkan Studies 8:123-126.

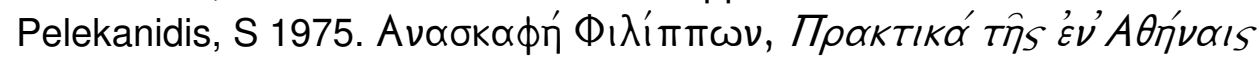

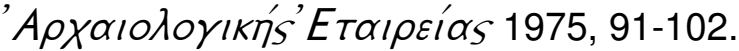

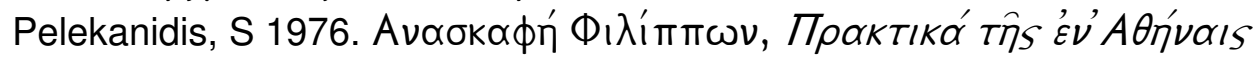

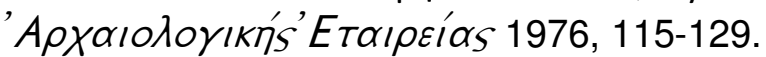

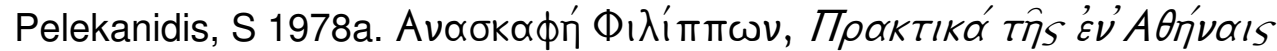
'Apxaioגorikńs' Etaipeías 1978, 64-72.

Pelekanidis, S 1978b. Kultprobleme in Apostel-Paulus-Oktagon von Philippi im Zusammenhang mit einem älteren Heroenkult, in Atti del IX Congresso Internazionale di Archeologia Cristiana II, 393-397. Rome: Istituto di Archeologia Cristiana.

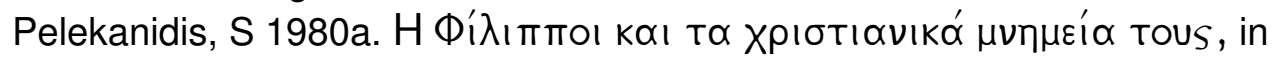

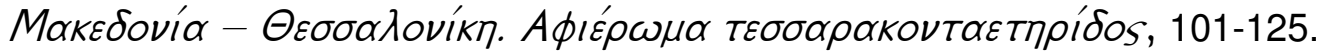

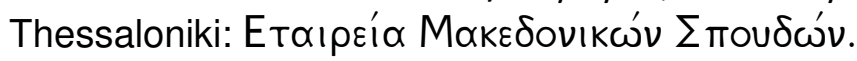

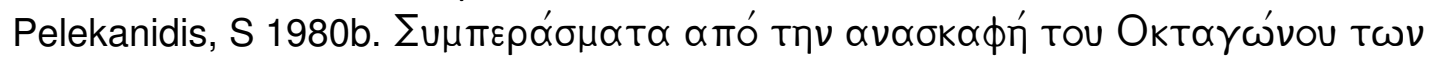

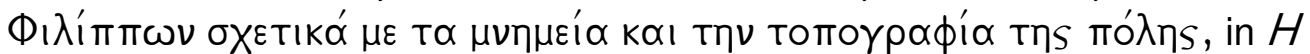

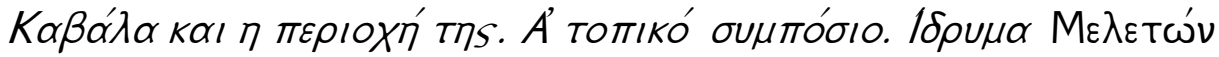
Xepбovíoou tou Aífuou 189, 149-158. Thessaloniki.

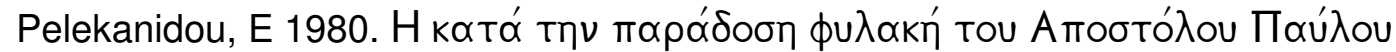

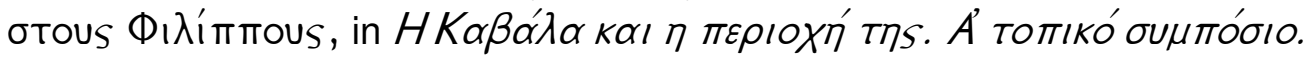

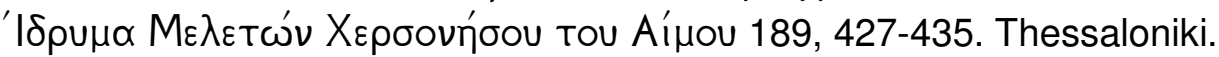

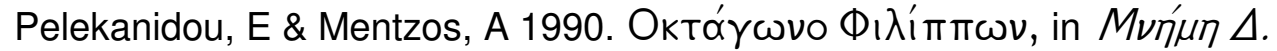

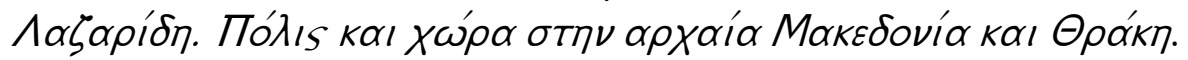

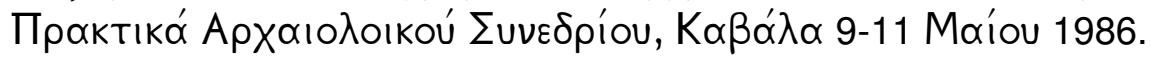

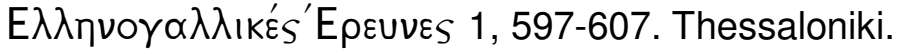

Penna, C 1995. Early Christian Burials at Philippi. Byzantinische Forschungen 21, 215-227.

Pilhofer, P 2000. Philippi II: Katalog der Inschriften von Philippi. Tübingen: Mohr. (WUNT 119.)

Pilhofer, S 2006. Romanisierung in Kilikien? München: Herbert Utz. (Quellen und Forschungen zur Antiken Welt 46.)

Price, S 1999. Religions of the Ancient Greeks. Cambridge: University Press.

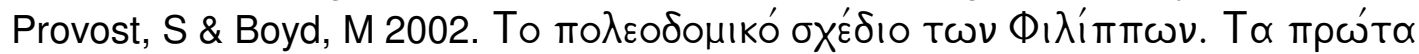

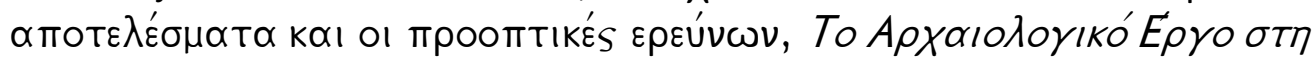

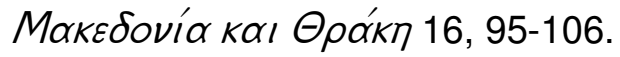

Roger, J 1938. L'enceinte basse de Philippes, Bulletin de Correspondance Hellénique 62, 20-41.

Sève, M 2000. De la naissance à la mort d'une ville: Philippes en Macédoine. Histoire Urbaine 1, 187-204. 
Thür, $\mathrm{H}$ 1995a. The processional way in Ephesos as a place of cult and burial, in Koester, H, Ephesos, Metropolis of Asia, 157-199. Valley Forge, PA: Trinity International.

Thür, H 1995b. Der ephesische Ktistes Androklos und (s)ein Heroon am Embolos. Jahreshefte des Östereichischen archäologischen Institutes in Wien 64, 63103.

Tzanavari, K 2003. The worship of gods and heroes in Thessaloniki, in Grammenos, D V (ed), Roman Thessaloniki, 177-262. Thessaloniki: Archaeological Museum.

Verhoef, E 2005. The church of Philippi in the first six centuries of our era. HTS 61, 565-592.

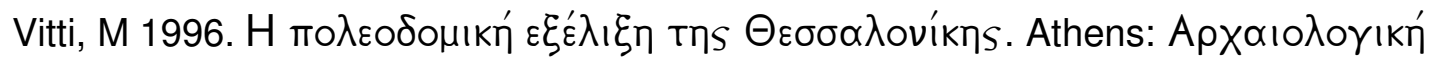

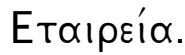

Witt, R 1977. The Kabeiroi in Ancient Macedonia, in $\Theta E \Sigma \Sigma$ A ONIKH ФI^IחПOY $B A \Sigma I \wedge I \Sigma \Sigma A, 1985,964-977$. Thessaloniki: Archaeological Museum. 
Syncretism in the church of Philippi

E G N A T I A

FIGURE 1

SITUATION BEFORE 300 A.D.

Width 27 meters, length 75 meters

(C) EDUARD VERHOEF
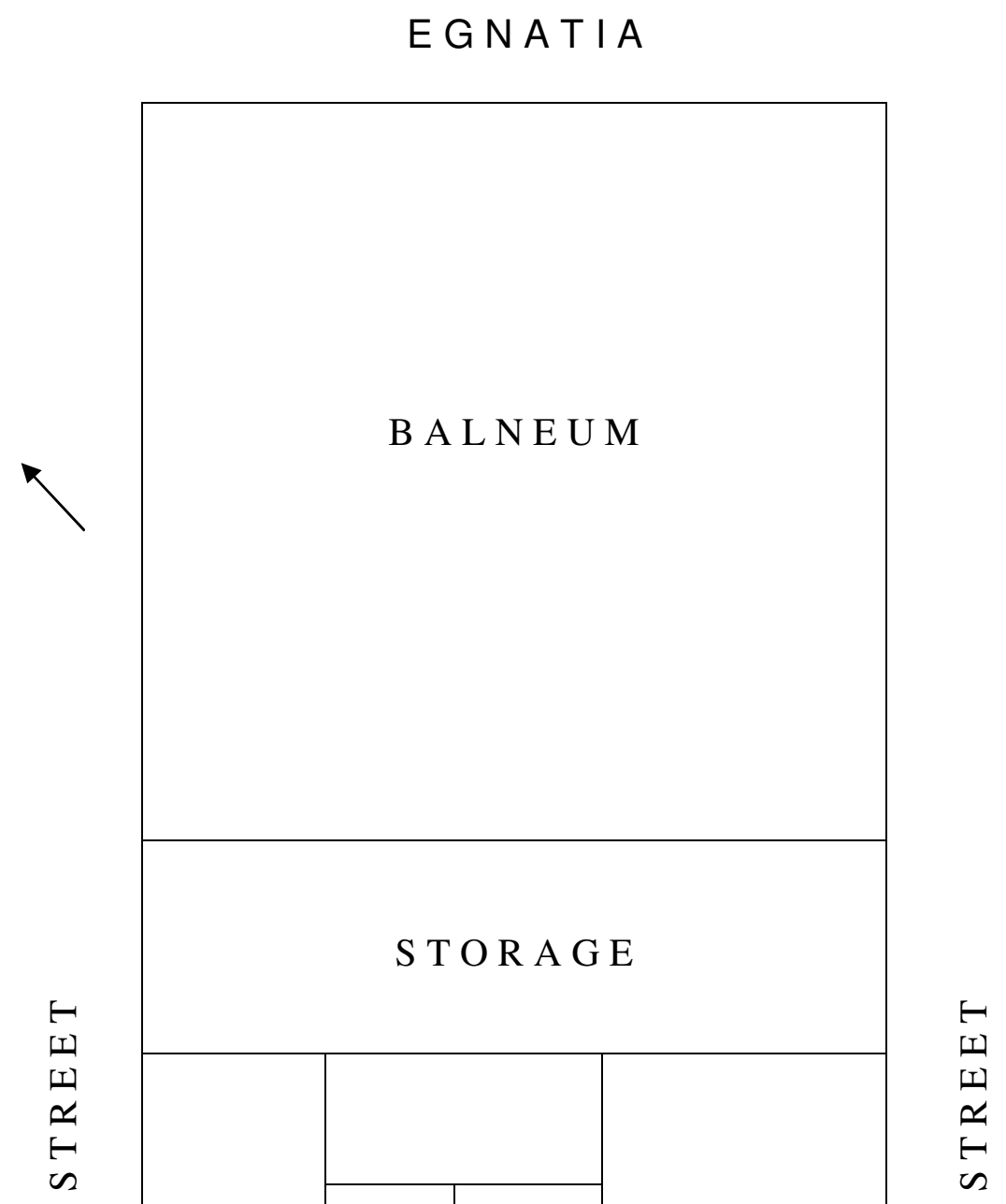

TE M E N O S

STREET 
E G N A T I A

FIGURE 2

SITUATION \pm 320 A.D.

Width 27 meters, length 75 meters

( ) EDUARD VERHOEF

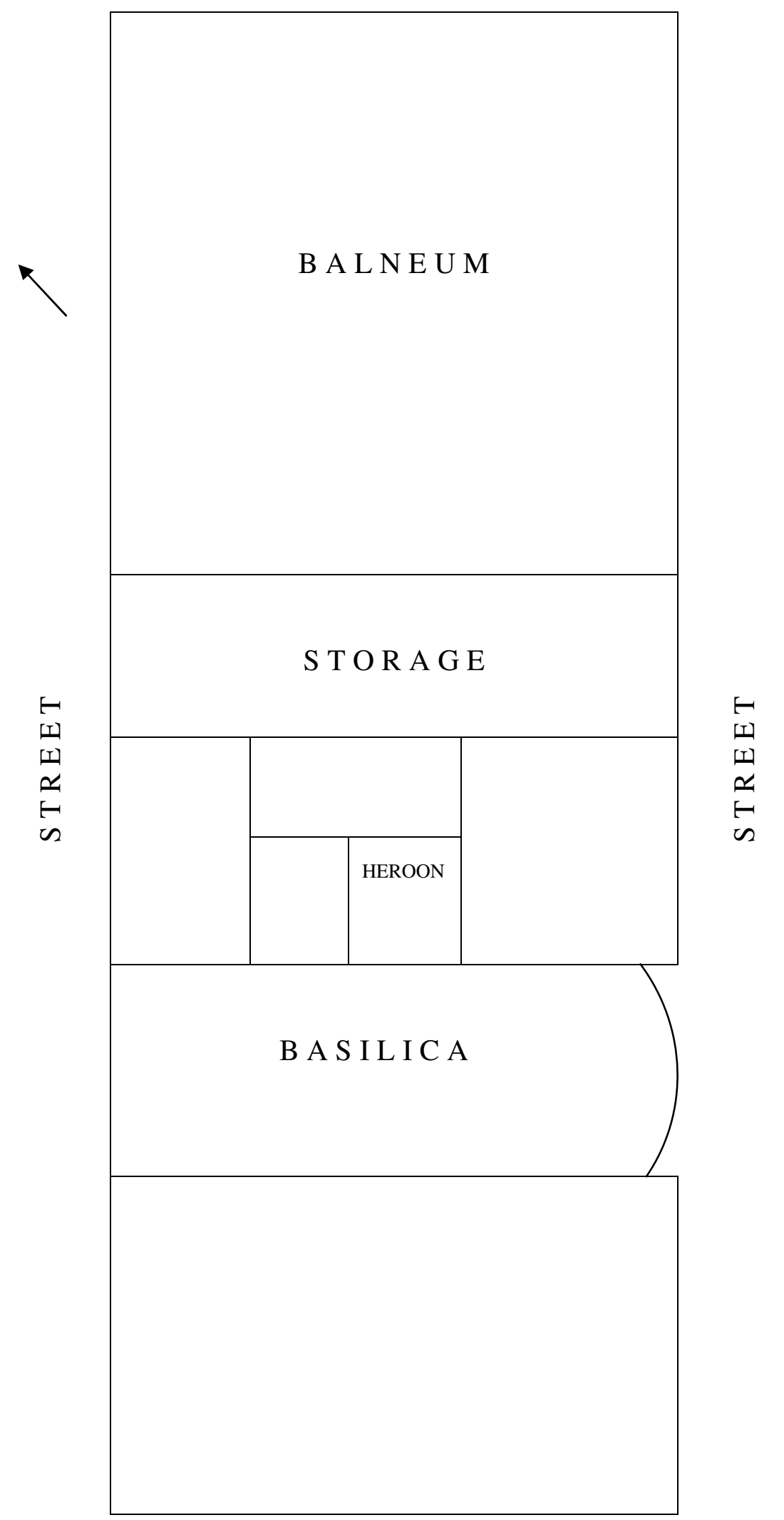

STREET 
E G N A T I A

FIGURE 3

SITUATION 5th-6th CENTURY

Width 27meters, length 75 meters

(C) EDUARD VERHOEF
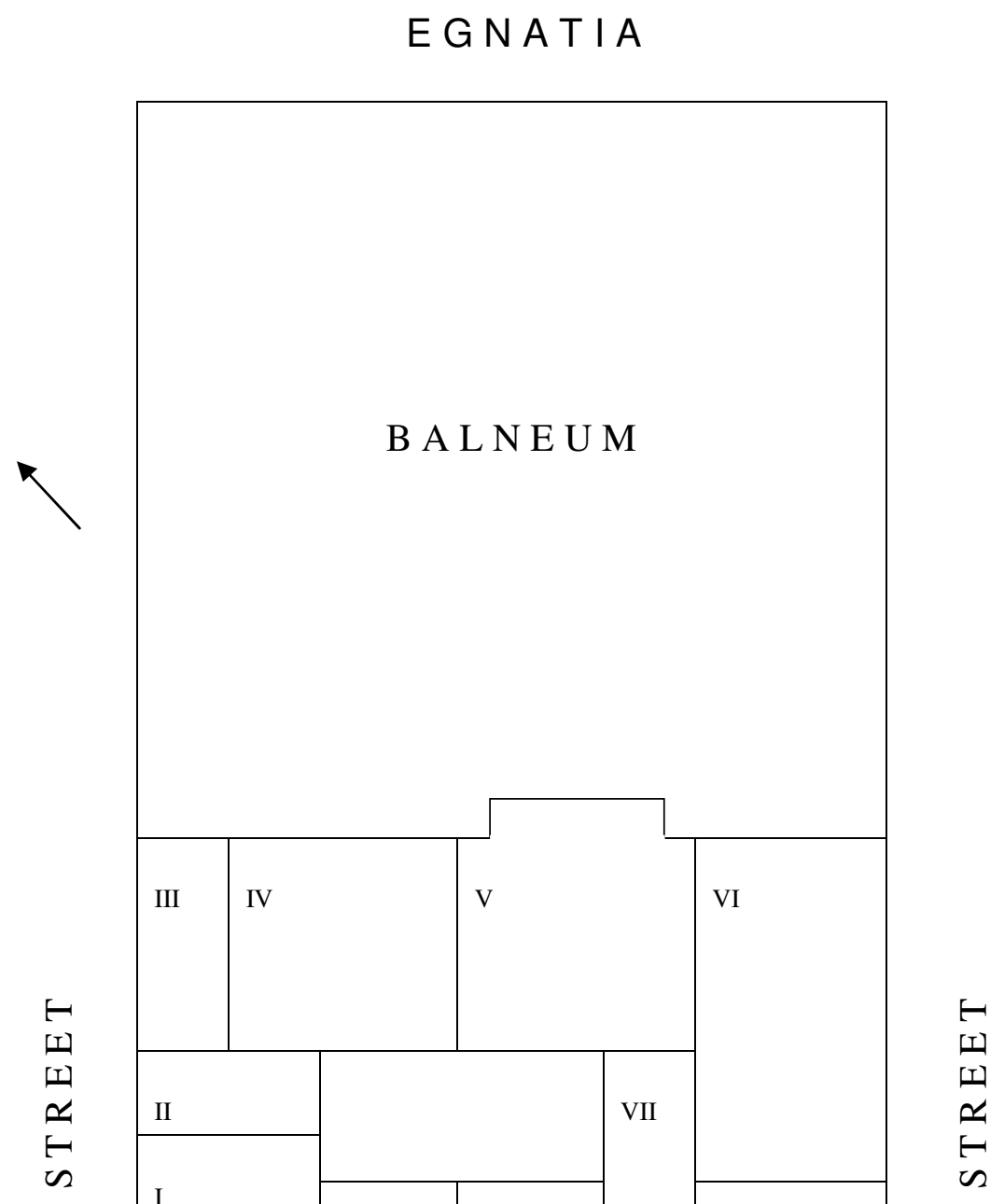

STREET 